\title{
Correction to: Cultivating Teacher Resilience
}

\author{
Caroline F. Mansfield $(D$
}

\section{Correction to: \\ C. F. Mansfield (ed.), Cultivating Teacher Resilience, https://doi.org/10.1007/978-981-15-5963-1}

The original version of the book was inadvertently published with error in a link and this has been corrected as "http://www.entree-online.eu/" in Chapters "1, 2, 7, 8 and 9". The correction chapters and book have been updated with the changes.

Open Access This chapter is licensed under the terms of the Creative Commons Attribution 4.0 International License (http://creativecommons.org/licenses/by/4.0/), which permits use, sharing, adaptation, distribution and reproduction in any medium or format, as long as you give appropriate credit to the original author(s) and the source, provide a link to the Creative Commons license and indicate if changes were made.

The images or other third party material in this chapter are included in the chapter's Creative Commons license, unless indicated otherwise in a credit line to the material. If material is not included in the chapter's Creative Commons license and your intended use is not permitted by statutory regulation or exceeds the permitted use, you will need to obtain permission directly from the copyright holder.

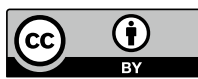

The updated versions of these chapters can be found at https://doi.org/10.1007/978-981-15-5963-1_1 https://doi.org/10.1007/978-981-15-5963-1_2 https://doi.org/10.1007/978-981-15-5963-1_7 https://doi.org/10.1007/978-981-15-5963-1_8 https://doi.org/10.1007/978-981-15-5963-1_9

(C) The Author(s) 2021

C. F. Mansfield (ed.), Cultivating Teacher Resilience, https://doi.org/10.1007/978-981-15-5963-1_19 